\title{
STUDI INTENSITAS SUARA DI BAGIAN PRODUKSI PT. RAJA BESI SEMARANG TAHUN 2015
}

\author{
Afif Ma'rifatuluthfi ${ }^{1}$, Susiyanti²). \\ Jurusan Kesehatan Lingkungan, Politeknik Kesehatan Kemenkes Semarang, \\ Jl. Raya Baturaden KM 12 Purwokerto, Indonesia
}

\begin{abstract}
Abstrak
Lingkungan yang sehat mencakup lingkungan tempat kerja yang terbebas dari unsur-unsur yang menimbulkan gangguan kesehatan seperti kebisingan yang melebihi ambang batasBagaimana Intensitas suara dan upaya pengendalian pada bagian produksi pabrik besi PT. Raja Besi Semarang. Mengetahui intensitas suara dan upaya pengendalian pada bagian produksi pabrik besi PT. Raja Besi Semarang.Metode penelitian deskriptif. untuk menggambarkan kondisi pabrik besi bagian produksi PT.Raja Besi Semarang dengan sajian tabel dan narasi data. Hasil pengukuran intensitas suara dibagian produksi di PT.Raja Besi Semarang dengan 13 titik lokasi pengukuran setelah dibandingkan dengan Permenakertras No.PER.13/MEN/X/2011 Tentang Nilai Ambang Batas Faktor Fisika dan Faktor Kimia di tempat kerja ada 8 lokasi yang melebihi NAB, dan ada 5 lokasi yang tidak melebihi NAB. Upaya pengendalian yang dilakukan untuk sumber bising dilakukan perawatan mesin secara rutin dalam 1 bulan sekali. Sedangkan, upaya pengendalian bising pada tenaga kerja yaitu dengan cara pengaturan jam kerja dan terdapat Standar Operasional Prosedur (SOP) untuk melaksanakan pekerjaan sesuai dengan prosedur yang ada. Simpulan dari penelitian ini adalah intensitas suara yangdihasilkan dibagian produksi PT. Raja Besi Semarang melebihi nilai ambang batas (NAB). Sedangkan upaya pengendalian yang dilakukan untuk mengurangi kebisingan adalah perawatan mesin-mesin.
\end{abstract}

Kata kunci : intensitas suara, industri, kesehatan lingkungan

\begin{abstract}
A healthy environment includes workplace environment that is free from elements that cause health problems such as noise that exceeds the threshold of sound intensity batasBagaimana and control efforts in the production of iron factory PT. Raja Besi Semarang. Knowing the intensity of the sound and control efforts in the production of iron factory PT. Raja Besi Semarang.Metode descriptive study. to describe the condition of the iron factory production PT.Raja Besi Semarang with a dish tables and narrative data. Sound intensity measurement results in the production section PT. Raja Besi Semarang with 13 points after the measurement location compared to Permenakertras No.PER.13 / MEN / X / 2011, On the Threshold Limit Value Factor Physical and Chemical Factors in the workplace there are 8 locations that exceed $N A B$, and there are five locations that do not exceed the NAB. Efforts are being made to control the noise source routine engine maintenance performed within 1 month. Meanwhile, efforts to control noise in the labor force that is by setting work hours and there is a Standard Operating Procedure (SOP) to carry out the work in accordance with existing procedures. The conclusions of this study is the intensity of the sound produced by the production section PT. RajaBesi Semarang exceeding the threshold value (NAV). While the control measures taken to reduce the noise is maintenance machines.
\end{abstract}

Keywords : sound intensity, industrial, environmental health

\section{PENDAhuluaN}

Undang-undang Republik Indonesia Nomor 36 Tahun 2009 tentang kesehatan pasal 162 dan pasal 163 menjelaskan bahwa upaya kesehatan lingkungan ditujukan untuk mewujudkan kualitas lingkungan yang sehat, mencapai derajat yang setinggi-tingginya. Lingkungan yang sehat mencakup lingkungan pemukiman, tempat kerja, tempat rekreasi serta tempat umum dan fasilitas umum yang bebas dari unsur-unsur yang menimbulkan gangguan kesehatan seperti limbah cair, limbah padat, limbah gas, sampah

1) E-mail: afif.gopip@ yahoo.co.id

2) E-mail: dolphin_fatih_a@yahoo.com yang tidak diproses sesuai dengan persyaratan yang telah ditetapkan pemerintah, binatang pembawa penyakit, zat kimia berbahaya, kebisingan yang melebihi ambang batas, radiasi pengion dan non pengion, air yang tercemar, udara yang tercemar, serta makanan yang terkontaminasi.

Soeripto M (2008, hal 324) menjelaskan bahwa, Kebisingan adalah bunyi yang tidak dikehendaki. Pengaruh gangguan kebisingan tergantung kepada intensitas dan frekuensi nada. Kebisingan merupakan salah satu faktor penting penyebab terjadinya stress 
dalam kehidupan dunia modern. Kebisingan dapat mempengaruhi kesehatan manusia. Pengaruhnya berupa peningkatan sistem kardiovaskular dalam bentuk kenaikan tekanan darah dan peningkatan denyut jantung. Apabila kondisi tersebut tetap berlangsung dalam waktu yang lama, akan muncul reaksi psikologis berupa penurunan konsentrasi dan kelelahan.

Menurut WHO, terdapat 250 juta $(4,2 \%)$ penduduk dunia mengalami gangguan pendengaran dan sekitar 75-140 juta (50\%) berada di Asia Tenggara. Dalam hal ini Indonesia menempati urutan ke-4 di Asia Tenggara, yaitu 4,6\% sesudah Srilangka $(8,8 \%)$. Survey kesehatan indera di tujuh propinsi diketahui bahwa $0,4 \%$ penduduk Indonesia menderita ketulian dan $16,8 \%$ penduduk Indonesia menderita gangguan pendengaran. Jadi diperkirakan sekitar 4 juta penduduk Indonesia tidak dapat mendengar dengan baik. Yuliani (Anonim, 2007).

PT. Raja Besi Semarang berdiri sejak 22 Januari 1973 sebagai PMDN diatas areal 3.5 hektar. Perusahaan ini terletak di Jalan Setia Budi 117, Kecamatan Banyumanik, Kabupaten Semarang, Propinsi Jawa Tengah, memperkerjakan lebih dari 1.000 orang. Raja Besi Semarang merupakan salah satu perusahaan pembuatan pipa dan kanal serta proses penipisan baja lembaran atau strip.Perusahaan ini pada awalnya merupakan usaha home industri yang karena perkembangannya serta untuk mengantisipasi kebutuhan pasar maka berkembang hingga sekarang ini yang produksinya mampu bersaing dipasaran. Produk yang di hasilkan antara lain : Produk Galvanized Steel Pipes, Carbon Steel ipes, C / Lip Channel Steel, Rectengel Steel Pipes, Conduit Steel Pipes dan CR / HR Steel Sheet dengan kapasitas produksi hingga 200.000 metrik ton per tahun. Proses produksibesi berpotensi untuk menimbulkan kebisingan di ruang produksi berupa suara-suara mesin dan kegiatan di dalam ruang produksi saat karyawan bekerja.

Resiko yang timbul akibat kebisingan pada karyawan adalah kerusakan pendengaran atau gangguan pendengaran yang disebabkan karena tingkat kebisingan terlalu tinggi. Kebisingan juga menggangu percakapan sehingga akan mempengaruhi komunikasi yang sedang berlangsung dan kebisingan tersebut juga menggangu konsentrasi karyawan dalam bekerja sehingga dapat menurunkan produktivitas kerja (Novantri Faradilla, Andi Rahmadiansah, Dyah Sawitri).

Kebisingan dapat mempengaruhi kesehatan manusia. Pengaruhnya berupa peningkatan sensitivitas tubuh seperti peningkatan sistem kardiovaskular dalam bentuk kenaikan tekanan darah dan peningkatan denyut jantung. Sehingga akan muncul reaksi psikologis berupa penurunan konsentrasi dan kelelahan. Budiman Chandra (2007, hal 169). Kebisingan tingkat tinggi dapat menyebabkan efek jangka pendek dan jangka panjang pada pendengaran. Semakin tinggi intensitas dari kebisingan, potensi untuk menimbulkan berbagai gangguan berikut semakin besar. Budiman Chandra (Waldron, 1990; Anies, 2004).

Perumusan masalah, bagaimana intensitas suara dan upaya pengendalian pada bagian produksi pabrik besi PT. Raja Besi Semarang

Tujuan, mengetahui intensitas suara dan upaya pengendalian pada bagian produksi PT. Raja Besi Semarang.

\section{BAHAN DAN METODE}

Jenis penelitian adalah penelitian deskriptif yaitu untuk memperoleh informasi tentang intensitas suara dan upaya pengendalian kebisingan bagian produksi di pabrik Besi PT. Raja Besi Semarang.

Subyek penelitian ini adalah intensitas suara dan upaya pengendalian kebisingan pada bagian produksi pabrik besiPT. Raja Besi Semarang meliputi 13 lokasi titik sampel, 100 responden, jumlah mesin, jenis mesin, waktu pengoperasian mesin, lama kerja, jumlah pekerja dan gangguan kebisingan terhadap pekerjanya.

\section{III.HASIL DAN PEMBAHASAN}

\section{Hasil}

Sunber kebisingan berdasarkan keterangan yang diperoleh dari hasil wawancara pada penanggung jawab pabrik Besi bagian produksi PT. Raja Besi sumber kebisingan yang ada di PT.Raja Besi Semarang berasal dari suara mesin-mesin yang ada di semua ruang produksi.

Jenis mesin dan jumlah mesin, di dalam proses produksi mesin-mesin yang digunakan mempunyai fungsi dan jumlah yang berbeda, jumlah mesin di PT. Raja Besi Semarang sebanyak 30.

Waktu pengoprasian Mesin, berdasarkan keterangan yang diperoleh dari hasil wawancara pada penanggung jawab pabrik besi bagian produksi PT. Raja Besi waktu pengoperasian mesin dilakukan setiap hari selama 24 jam, kecuali hari Sabtu mesin dioprasikan selama 18 jam.

Hasil pengukuran intensitas suara dari 13 titik, yang melebihi NAB ada 8 lokasi dan 5 lokasi lainnya masih dibawah $\mathrm{NAB}$, lokasi yang paling tinggi intensitas suaranya adalah pada ruang kompresor yaitu $97.26 \mathrm{~dB}$ dan lokasi yang paling rendah intensitas suaranya adalah ruang mesin cat siku yaitu $73.73 \mathrm{~dB}$.

Upaya pengendalian pada sumber bising yang dilakukan oleh PT.Raja Besi Semarang adalah upaya pengendalian teknis, upaya pengendalian dengan caraperawatan mesin produksi yaitu membersihkan mesin-mesin setiap 1 bulan sekali secara rutin, dan memeperbaiki/mengganti mesin yang rusak.

Upaya pengendalian administrative pada tenaga kerja yang sudah dilakukan oleh PT. Raja Besi Semarang yaitu penerapan shift kerja atau pembagian shift kerja, pada bagian produksi, terdapat ruang khusus untuk operator yang terpisah dari ruang 
mesin. Terdapat Standar Operasional Prosedur (SOP) untuk melaksanakan pekerjaan sesuai dengan prosedur yang ada.Pelatihan K3 (Keselamatan dan Kesehatan Kerja) Berdasarkan keterangan yang diperoleh dari hasil wawancara pada penanggung jawab pabrik Besi bagian produksi PT. Raja Besi Semarang adalah Pentingnya Alat Pelindung Diri dan Standar Oprasional Prosedur.

Jenis alat pelindung diri yang disediakan oleh PT. Raja Besi Semarang adalah helmet, sarung tangan, masker, kaca mata, Ear plug, safty boot, dan wearpack, sarung tangan, masker dan safety boot dibedakan menurut bagian kerjanya, wearpack dibedakan menurut warna pada setiap bagian bagiannya dan kaca mata digunakan khusus pada bagian pemanasan besi.

Gangguan-gangguan Kesehatan yang di Alami Pekerja berdasarkan hasil wawancara terhadap 100 karyawan, jenis gangguan-gangguan yang dialami oleh karyawan PT. Raja Besi Semarang yang ditimbulkan oleh proses produksi besi adalah gangguan pendengaran, sulit berkonsentrasi, mudah marah, gangguan tidur dan ada yang tidak mengalami gangguan kesehatan.

\section{Pembahasan}

Sumber kebisingan yang ada di PT.Raja Besi Semarang berasal dari suara mesin-mesin yang ada di semua ruang produksi. Sumber yang paling bising yaitu berada pada Ruang Kompresor karena pada ruang ini terdapat lebih banyak mesin dari pada ruangan lainnya dan semua mesin tersebut menyala secara bersamaan serta kondisi ruang yang sempit sehingga intensitas suara yang dihasilkan menjadi lebih besar maka dari itu ruang kompresor ini kebisingannya tinggi.

Jenis mesin dan Jumlah mesin di dalam proses produksi mesin-mesin yang digunakan mempunyai fungsi dan jumlah yang berbeda, adapun mesin-mesin yang digunakan dalam proses produksi digolongkan menjadi tujuh yaitu : pickling, mesin potong I, rolling, annealing, mesin potong II, mesin pipa dan mesin drat. Dengan jumlah seluruh mesin ada 30 mesin. dengan tiap - tiap mesin memiliki jumlah mesin lebih dari 1 mesin, yang paling banyak yaitu pada mesin pipa terdapat 12 mesin pipa, pada mesin potong dibagi menjadi dua yaitu mesin potong I dan mesin potong II yang jumlah keseluruhan ada 8 mesin potong dan sisanya mesin yang lainnya.

Waktu pengoprasian Mesin berdasarkan keterangan yang diperoleh dari hasil wawancara pada penanggung jawab pabrik besi bagian produksi PT. Raja Besi waktu pengoperasian mesin dilakukan setiap hari selama 24 jam, kecuali pada hari Sabtu mesin beroprasi selama $18 \mathrm{Jam}$.

Hasil Pengukuran Intensitas SuaraMenurut Permenakertrans NO.PER.13/MEN/X/2011 tentang NAB faktor fisika dan kimia di tempat kerja menyebutkan waktu pemajanan yang diperbolehkan bahwa tingkat kebisingan di ruang kerja adalah 85 dBA dalam 8 jam kerja per hari

Berdasarkan hasil pengukuran kebisingan di bagian produksi PT. Raja Besi Semarang Jalan Setia Budi 117 Semarang Srondol Kulon Kecamatan Banyumanik Kabupaten Semarang dari 13 titik lokasi pengukuran yang melebihi NAB ada 8 lokasi yaitu Ruang Mesin Pickling, Ruang Mesin Rolling, Ruang Mesin CAG Galvanish, Ruang Mesin Pipa G dan F, Ruang Kompresor, Ruang Mesin Drat, Ruang Pemotongan Pipa dan Ruang Mesin Potong. Lokasi yang paling tinggi intensitasnya adalah pada Ruang Kompesor yaitu 97.26 dB. Hal ini disebabkan karena pada ruang ini terdapat lebih banyak mesin dari pada ruangan lainnya dan semua mesin tersebut menyala secara bersamaan serta kondisi ruang yang sempit sehingga intensitas suara yang dihasilkan menjadi lebih besar maka dari itu ruang kompresor ini kebisingannya tinggi, untuk mengatasi masalah kebisingan tersebut maka mesin - mesin di ruang produksi harus di beri peredam suara, untuk pekerja agar tidak mengalami gangguaan akibat kebisingan harus memakai alat pelindung diri berupa ear plug, 5 lokasi yang tidak melebihi NAB yaitu Ruang IPAL, Ruang Mesin Cat, Ruang Messin Boiler, Gudang dan Kantor. Lokasi yang paling rendah intensitas suaranya adalah Ruang Mesin Cat Siku yaitu 73.73 dB. Hal ini disebabkan karena ruang mesin cat siku terbuka dan mesin - mesin di ruang ini mengeluarkan intensitas suara yang rendah sehingga tidak menimbulkan kebisingan yang tinggi.

Upaya - upaya pengendalian yang dilakukan oleh PT. Raja Besi Semarang adalah sebagai berikut :

1. Upaya pengendalian teknis yang di lakukan pada alat upaya pengendalian dengan caraperawatan mesin produksi yaitu membersihkan mesin-mesin setiap 1 bulan sekali secara rutin, dan memeperbaiki/mengganti mesin yang rusak.

2. Upaya pengendalian administratif yang di lakukan pada tenaga kerja yang sudah dilakukan oleh PT. Raja Besi Semarang pada bagian produksi adalah penerapan shift kerja atau pembagian shift kerja di PT. Raja Besi Semarang pada bagian produksi, terdapat ruang khusus untuk operator yang terpisah dari ruang mesin. Terdapat Standar Operasional Prosedur (SOP) untuk melaksanakan pekerjaan sesuai dengan prosedur yang ada.

3. Pelatihan K3 (Keselamatan dan Kesehatan Kerja) Berdasarkan keterangan yang diperoleh dari hasil wawancara pada penanggung jawab pabrik Besi bagian produksi PT. Raja Besi untuk pelatihan K3 yang sudah mendapatkan adalah kepala-kepala bagian dan pekerja seperti pelatihan K3 tentang Pentingnya Alat Pelindung Diri dan Standar Oprasional Prosedur.

Jenis alat pelindung diri yang disediakan oleh PT.Raja Besi Semarang adalah helmet, sarung tangan, masker, kaca mata, Ear plug, safty boot, dan wearpack. sarung tangan, masker dan safety boot dibedakan menurut bagian kerjanya, 
wearpack dibedakan menurut warna pada setiap bagian, dan kaca mata digunakan khusus pada bagian pengelasan besi.

Berdasarkan hasil kuesioner dari 100 pekerja, yang memakai alat pelindung diri pendengaran selama di area bising pada waktu menyelesaikan pekerjaan adalah 16 pekerja. Dan yang tidak memakai alat pelindung diri selama di area bising pada waktu menyelesaikan pekerjaan adalah 84 pekerja. Pekerja yang tidak memakai alat pelindung diri lebih banyak dari pada yang memakai alat pelindung diri sedangkan di PT. Raja Besi sudah disediakan alat pelindung diri secara lengkap dan mencukupi. Hal ini disebabkan banyak pekerja yang malas untuk memakai alat pelindung diri tersebut. Untuk mengatasi hal ini perlu adanya himbauan, peraturan dan sanksi kepada para pekerja tentang alat pelindung diri tersebut supaya pekerja tertib memakai alat pelindung diri. Dan perlu adanya pengetahuan melalui pelatihan - pelatihan lagi tentang pentingnya memakai alat pelindung diri, agar pekerja mengetahui bahaya - bahaya apa saja yang ditimbulkan apabila mereka tidak memakai alat pelindung diri.

Gangguang-gangguan Kesehatan yang di Alami Pekerja. Menurut Soeripto M (2008, h. 339) menjelaskan bahwa "kebisingan dapat menyebabkan berbagai pengaruh terhadap tenaga kerja, yaitu : pengaruh fisiologi, pengaruh psikologis, gangguan komunikasi, dan ketulian". Dan menurut Permenaker No. 13 Tahun 2011 Pasal 1 ayat 19 " Kebisingan adalah semua suara yang tidak dikehendaki yang bersumber dari alat -alat proses produksi dan atu alat - alat kerja yang pada tingkat tertentu dapat menimbulkan gangguan pendengaran.

Berdasarkan hasil wawancara terhadap 100 karyawan PT. Raja Besi Semarang, jenis gangguan-gangguan yang dialami oleh karyawan yang ditimbulkan oleh proses produksi besi adalah gangguan pendengaran sebanyak 62 orang, sulit berkonsentrasi 8 orang, mudah marah 7 orang, gangguan tidur 2 orang dan yang tidak mengalami gangguan kesehatan ada 21 orang. Gangguan kesehatan yang paling banyak dialami oleh karyawan adalah gangguan pendengaran dan dialami oleh pekerja yang berada di ruang kompresor hal ini disebabkan karena intensitas suara di ruang produksi tinggi, tidak memakai alat pelindung diri pendengaran selama mereka berada di area bising pada waktu menyelesaikan pekerjaan. Untuk meminimalisir terjadinya gangguan pendengaran pada karyawan yang lebih banyak lagi, maka dapat dilakukan dengan cara memasang alat peredam suara pada mesin yang intensitas suaranya tinggi, membuat pengaturan rotasi kerja dan melakukan pemeriksaan kesehatan terhadap tenaga kerja. Untuk karyawan dihimbau, peraturan tentang memakai alat pelindung diri dipertegas bila perlu dikenakan sanksi yang lebih berat sehingga karyawan tidak malas untuk memakai alat pelindung diri.

\section{IV.KESIMPULAN}

Proses produksi dibagian produksi PT. Raja Besi Semarang adalah berawal dari mesin pickling, kemudian mesin potong 1 , mesin rolling mill, mesin annealing, mesin potong 2 dan mesin pipa.

Sumber kebisingan yang ada di PT.Raja Besi Semarang berasal dari suara mesin-mesin yang ada di semua ruang produksi. Sumber yang paling bising yaitu berada pada Ruang Kompresor dengan intenssitas suara $97.26 \mathrm{~dB}$.

Hasil pengukuran kebisingan dibagian produksi PT. Raja Besi Semarang dari 13 titik lokasi pengukuran setelah dibandingkan dengan Permenakertras No.PER.13/MEN/X/2011 Tentang Nilai Ambang Batas Faktor Fisika dan Faktor Kimia di tempat kerja ada 8 lokasi yang melebihi NAB yaitu Ruang Mesin Pickling, Ruang Mesin Rolling, Ruang Mesin CAG Galvanish, Ruang Mesin Pipa G dan F, Ruang Kompresor, Ruang Mesin Drat, Ruang Pemotongan Pipa dan Ruang Mesin Potong. Intensitas suara yang paling tinggi ruang kompresor yaitu 97.26 dB. 5 lokasi yang tidak melebihi NAB yaitu Ruang IPAL, Ruang Mesin Cat, Ruang Messin Boiler, Gudang dan Kantor, intensitas suara yang paling rendah ruang mesin cat siku yaitu $73.73 \mathrm{~dB}$.

Upaya pengendalian kebisingan pada bagian produksi di PT. Raja Besi Semarang dengan cara teknis yaitu perawatan mesin produksi yaitu membersihkan mesin-mesin setiap 1 bulan sekali secara rutin, dan memeperbaiki/mengganti mesin yang rusak dan administratif yaitu seperti penerapan shift kerja atau pembagian shift kerja dan pelatihan K3.

Jenis alat pelindung diri yang digunakan oleh pekerja di bagian produksi PT. Raja Besi Semarang adalah helmet, sarung tangan, masker, kaca mata, ear plug, safty boot dan wearpack.

Gangguan kesehatan yang dialami oleh pekerja di bagian produksi PT. Raja Besi Semarang adalah gangguan pendengaran.

\section{DAFTAR PUSTAKA}

A. Aziz Hidayat, 2007, Metode Penelitian Kebidanan dan Teknik Analisis Data, Jakarta : Salemba Medika.

Andan T Dinata, 2011, www.byantech.com, tentang Proses Pengolahan Besi.

Budiman Chandra, 2007, Pengantar Kesehatan Lingkungan, Jakarta : Penerbit Buku Kedokteran EGC. 
Departemen Kesehatan RI, 1987. Permenkes No. 718/Men/Kes/Per/1987, tentang Kebisingan yang berhubungan dengan kesehatan, Jakarta : Departemen Tenaga Kerja RI.

Novantri Faradilla, Andi Rahmadiansah, Dyah Sawitri, Pengendalian Kebisingan Pada Industri Pencuci Pasir Di PT. Maharadia Prakarsa Rembang - Jawa Tengah.

Republik Indonesia, Kementerian Tenaga Kerja dan Transmigrasi, 2011, Permenakertrans no. 13/MEN/X/2011 Tentang Nilai Ambang Batas Faktor Fisika dan Faktor Kimia di Tempat Kerja, Jakarta: http://ppid.bnp2tki.go.id/jdih/index.php/perme n/141-peraturan-menteritenaga-kerja-dantransmigrasi-nomorper12menx2011 diakses pada tanggal 12 februari 2014 pkl 10.24 WIB.

Republik Indonesia, Kepmenkes, 2009, UndangUndang Republik Indonesia Nomor 36 Tahun 2009 Tentang Kesehatan, Jakarta : Kepmenkes RI.
Soeratman Ramli, 2010, Sistem Manajemen Keselamatan \& Kesehatan Kerja OSHAS 18001, cetakan kedua, Jakarta : Dian Rakyat.

Soeripto M, 2008, Higiene Industri, Jakarta: Fakultas Kedokteran UI.

Suma'mur PK, 2009, Higiene Perusahaan dan Keshatan Kerja (Hiperkes), Jakarta: Universitas Indonesia.

Tri Cahyono, 2014, Pedoman Penulisan Proposal dan Karya Tulis Ilmiah, Purwokerto: JKL Kemenkes Purwokerto.

Yuliani, 2014, Studi Deskriptif Intensitas Suara Bagian Produksi Pabrik Kayu UD. Kartika Sari Di Desa Prigi Kecamatan Sigaluh Kabupaten Banjarnegara Tahun 2014.

Yulianto, dkk, 2008. Buku Pedoman Praktikum Hiperkes. Purwokerto : Politeknik Kesehatan Semarang Jurusan Kesehatan Lingkungan. 